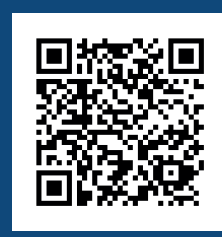

Keywords: Conservation Quillajaceae Seed storage Transplantation

Historic: Received 02/03/2018 Accepted 10/04/2018

Correspondence: sjevelazco@gmail.com
Santiago José Elías Velazcola+, Christopher Thomas Blumb, Pablo Melo Hoffmann²

\section{GERMINATION AND SEEDLINGS DEVELOPMENT OF THE THREATENED SPECIES Quillaja brasiliensis}

VELAZCO, S. J. E.; BLUM, C. T.; HOFFMANN, P. M. Germination and seedlings development of the threatened species Quillaja brasiliensis. CERNE, v. 24, n. 2, p. 90-97, 2018.

\section{HIGHLIGHTS}

Quillaja brasiliensis has a good germination rates which decreased after I.5 years storage.

Temperature of $25^{\circ} \mathrm{C}$ is better for mean germination time, germination viability and vigour.

Photoperiod improved the synchrony as shorter was the light period.

Transplantation did not have negative effects on seedling survival and growth.

\section{ABSTRACT}

Brazil is a mega diverse country, but as consequence of habitat degradation several plant species are threatened. Quillaja brasiliensis is a rare and threatened tree species of the temperate forests of South America. We investigated protocols for germination, seedling growth and transplantation. We discuss some ecological matters that could affect the species' establishment. We evaluated germination under a range of storage periods, temperature and light conditions, the effects of transplantation and the development of seedlings under two sowing methods. We found that seeds germinated rapidly and have a high germination rate. Temperature influenced germination vigour, and photoperiod influenced synchrony. There was increased and faster germination under controlled culture conditions. The high germination rate and rapid growth qualify $Q$. brasiliensis as a potential species for restoring degraded areas and enrichment programmes. 


\section{INTRODUCTION}

As elsewhere, the main threats to native plants in Brazil are habitat alteration for cattle ranching, agricultural expansion and mining (Martins et al., 2015). Since 2010 the National Centre for Flora Conservation has assessed the extinction risk of 5,165 species of the Brazilian flora ( 1 I .2\% of the national flora) and, as a result, 2,478 plant species are considered threatened at the national level (Martins et al., 2015). However, it is important to note the number of species assessed represents only c. 10\% of the Brazilian flora, and that the inclusion of a species in a national Red List does not necessarily increase the probability of its survival in nature (Moraes et al., 20I4).

In the Atlantic Rain Forest, c. 367 species of trees and shrubs are threatened (Tabarelli et al., 2003), including Quillaja brasiliensis (A.St.-Hil. \& Tul.) Mart. (CNCFlora, 2013). Commonly known as soap tree, because of the foam produced from its leaves and bark. Quillaja is a genus of the Quillajaceae family, and currently includes only two species, both in South America. $Q$. brasiliensis occurs in north-eastern Argentina associated with grassland, deciduous and semi-deciduous forest, in eastern Paraguay and northern Uruguay where it growths in riverine forest, and in southern Brazil (Reitz, 1996, Santander and González, 2007; Sakuragui, 2015).

In Brazil this species has an irregular and discontinuous distribution, occurring in the southern states of Paraná, Santa Catarina and Rio Grande do Sul (Reitz, 1996; Sakuragui, 2015). It is particularly rare in Paraná state, observed only in $7.7 \%$ of 26 surveyed forest remnants, with an abundance of 0.04 individuals per km (Hoffmann et al., 20I5).

Quillaja brasiliensis is usually found on the edges of the Araucaria Forest, an ombrophilous forest characterized by the dominance of Araucaria angustifolia, also associated with natural grassland (Reitz, 1996) and in deciduous forest (Carvalho, 2003). The species is characterized as perennial, a pioneer and heliophytic (Reitz, 1996), mean height is 10-20 m (Marchiori, 2000) although it also occurs as small tree or bush in the edge of watercourses or in rocky areas. Its leaves are simple, alternate, leathery and lance-shaped, with entire or serrate margin. The flowers are greenish gathered in small axillary corymbs. The fruits are formed by five follicles arranged in a star-shaped with dorsal or ventral dehiscence (Marchiori, 2000). The seeds are silver coloured, $5 \mathrm{~mm}$ long and $2 \mathrm{~mm}$ wide, with a one-sided papyraceous wing (Reitz, 1996).

Quillaja brasiliensis contains saponins in its leaves and bark (Reitz, 1996) and has multiple uses. These compounds have adjuvant activity in vaccines, with potential use in the pharmacological industry (Costa et al., 20I4; Müller and Schiedeck, 2018). Its wood has high mechanical strength in certain physic-mechanical properties, and it is exploited for construction, carpentry and fuelwood (Carvalho, 2003). Also is used as insecticide and medicinal, with diuretic, cicatrizing and antiseptic properties (Carvalho, 2003).

These various uses have resulted in the overexploitation of the species that, in combination with a reduction of its habitat, led it to be categorized as Endangered in Brazil and Paraguay. The species has not, however, been assess for the IUCN Red List. Restoration of threatened or locally rare species have the dual benefit of conservation of taxa and the recovery of sites (Hoffmann et al., 2015). The collection and banking of wild seed is important in habitat restoration and reintroduction of species (Hay and Probert, 2013). However, this requires knowledge about traits associated with reproductive biology, phenology, and propagation (Thomas et al., 2014).

The main objective of this research was to test the seed germination response to storage period and to different temperature and light conditions, and to test resistance to transplantation and seedling development under different sowing methods. Based on the results we discuss factors that could negatively affect the establishment of the species in the field.

\section{MATERIAL AND METHODS}

\section{Collection of Seeds}

The reproductive material was collected in Fernandes Pinheiro municipality $\left(25^{\circ} 35.255^{\prime} \mathrm{S}\right.$ and $50^{\circ} 27.528^{\prime} \mathrm{W}$ ) in Paraná state, Brazil, from a remnant of Araucaria Forest at $830 \mathrm{~m}$ altitude. Within the same forest remnant, Hoffmann et al. (2015) mapped trees of 14 endangered species aiming to collect seeds for restoration and conservation research.

The seeds were extracted from mature fruits. Considering the dehiscence of its fruits and the anemochory of its seeds, fruits were collected by placing a plastic tarpaulin on the ground around the trees and the branches were shaken. Experiments were conducted in the Native Species Propagation Laboratory of the Chauá Society, in Campo Largo municipality $\left(25^{\circ} 29.686^{\prime} S\right.$ and $49^{\circ} 29.058^{\prime} \mathrm{W}$ ), at $920 \mathrm{~m}$ altitude, in the same state. Both sites have the Köppen Cfb temperate climate type, with rains uniformly distributed, cool summers, no dry season and common frosts in winter (Kriticos et al., 20I2). The mean annual precipitation range is $1200-1400 \mathrm{~mm}$ and the mean temperature range $16-18^{\circ} \mathrm{C}$ (IAPAR, 20I5). 


\section{Germination experiments}

We performed three germination experiments to evaluate the effect of the storage period, the temperature and photoperiod, and the influence of two sowing methods on germination. Before each experiment was obtained the weight of one thousand seeds and the number of seeds per $\mathrm{Kg}$, performed using an electronic balance accurate to $0.1 \mathrm{mg}$, with eight repetitions of 100 randomly sampled seeds. Seed moisture was evaluated from three samples of seed of c. $5 \mathrm{~g}$ each. They were dried in an oven in a temperature of $105 \pm 3{ }^{\circ} \mathrm{C}$ for $24 \mathrm{~h}$ and then weighted for a second time. For each germination experiment we used four acrylic germination boxes, and each one was considered as an experimental unit. Within each acrylic box 30 seeds were placed on filter paper substrate and regularly watered with distilled water.

Storage period: To evaluate the effect of the storage period on germination we tested three storage periods: ( 1 ) immediately after collection (0 days), (2) after 365 days of storage, and (3) after 547 days of storage. Seeds were stored in transparent polypropylene containers in a fridge at $5^{\circ} \mathrm{C}$. The experiments were in a germination chamber at $25^{\circ} \mathrm{C}$ and $12 \mathrm{~h}$ of natural light.

Light and temperature: We established six treatments in a factorial arrangement, which combined two temperatures $\left(20\right.$ and $25^{\circ} \mathrm{C}$ ) and three photoperiods (dark, 12 and $24 \mathrm{~h}$ ) of artificial light, provided by a fluorescent lamp. The germination boxes were maintained in a germination chamber with controlled condition of photoperiod and temperature.

Sowing methods: We evaluated the influence of two sowing methods on germination. In the first treatment ( $\mathrm{TI}$ ) seeds were sowed in acrylic germination boxes maintained in a germination chamber at 25 ${ }^{\circ} \mathrm{C}$ and $12 \mathrm{~h}$ of natural light; in the second treatment (T2) sowing was in individual $280 \mathrm{~cm}^{3}$ cone-shaped plastic containers. The substrate used (for T2 only) was Mecplant ${ }^{\circledR}$, composed of stabilized pine bark, expanded vermiculite with moisture of $0.76 \mathrm{~cm}^{3}$ and a dry density of $0.36 \mathrm{~g} \cdot \mathrm{cm}^{3}$. The containers were placed in a greenhouse with naturally fluctuating temperature and light, with daily irrigation.

For all the experiments we recorded the number of seeds germinated per day and then calculated the germination rate (G; Equation I), germination velocity index (GVI; Equation 2), mean germination time (MGT; Equation 3) and synchrony index ( $Z$; Equation 4 and 5). For the storage period test only, germination rate was analysed. The formulas used to calculate the parameters were: Where $n_{g}$ - number of seeds germinated at the end of experiment and $n_{t}$ - the total number of seed sowed; Where $n_{i}$ - number of seeds germinated on the $i^{\text {th }}$ day; $x_{i}$ number of days from sowing and the $i^{\text {th }}$ day; and $k$ - the last day of observation; and $k$ - last time of germination; Where $n_{i}$ - number of seeds germinated on the $i^{t h}$ day; $t_{i}$ - time between the first germination and the $i^{i t h}$ day; and $k$ - last time of germination; Where $f_{i}$ - relative frequency of germination; $n_{i}$ - number of seeds germinated on the $i^{\text {th }}$ day; and $k$ - last time of germination.

$$
\begin{aligned}
& G=\left(n_{s} \cdot\left(n_{t}\right)^{-1}\right) \cdot 100 \\
& G V I=\sum_{i=1}^{k}\left(n_{i} \cdot\left(x_{i}^{-1}\right)\right) \\
& M G T=\sum_{i=1}^{k} n_{i} t_{i} \cdot\left(\sum_{i=1}^{k} n_{i}\right)^{-1} \\
& Z=-\sum_{i=1}^{k} f_{i} \log _{2} f_{i} \\
& f_{i}=n_{i} \cdot\left(\sum_{i=1}^{k} n_{i}\right)^{-1}
\end{aligned}
$$

\section{Effect of transplantation on seedling growth}

We evaluated the effect of replantion on seedling survival and growth using two treatments. In the first treatment ( $\mathrm{TI}$, direct sowing) the seeds were sown individually in cone-shaped plastic containers, placed with the long axis parallel to the substrate surface and then covered with a thin layer of substrate. In the second treatment (T2, seedlings replanted) seeds were sown on two sheets of filter paper in acrylic germination boxes, maintained in a germination chamber at $25^{\circ} \mathrm{C}$ and $12 \mathrm{~h}$ of natural light. Ten days after sowing, the seedlings were replanted in the same type of substrate, container and placed in the same greenhouse as for TI. The sowing date was the same for both treatments, and after sowing ( $\mathrm{TI}$ ) or replanting (T2), the containers were placed in a greenhouse with natural fluctuation of light and temperature and with daily irrigation. The substrate and containers were the same used in the germination experiment about sowing methods. We evaluated this experiment monthly along one semester: survival rates, total height above soil, diameter at soil level, height:diameter ratio (HDR) and the number of mature leaves.

\section{Data analysis}

For the germination experiments we fitted OLS models and tested the normality and homoscedasticity of the residuals. Variables that did not fulfil these conditions 
were transformed by the Box-Cox method prior to analysis. We then used an ANOVA with means adjusted by least squares and pairwise comparisons were made with the Tukey HDS test at $95 \%$ confidence level, with probabilities adjusted by the single step method. For survival data from the seedling experiment we used a GLM with binomial distribution and logit link function to estimate the probability of a seedling being alive. To analyse the relationship of the others parameters with time we used linear mixed models fitted by a restricted maximum likelihood approach. We considered individuals and treatments as random effects, with time and the variable measured as fixed effects. Individuals were considered as sample units for all models. All analyses were performed in R v. 3.2.2 (R Core Team, 2017) using the packages doBy, MASS, multcomp and nlme.

\section{RESULTS}

\section{Storage period}

Immediately after collection we recorded a mean of 162,602 seeds $\mathrm{kg}^{-1}$ (CV 4.35\%) and a mean seed weight of $5.88 \mathrm{mg}$. Seed moisture content at 0,365 and 547 days was, respectively, 7.65 (CV I.86\%), 8.00 (CV $4.26 \%$ ) and $6.72 \%$ (CV 13.99\%). Storage periods influenced germination rate negatively. Storage for one year did not affect the germination rate, but thereafter viability decreased significantly to $30 \%$ (Figure I). For all periods the first germination occurred on the 3rd or 4th day and the last on the 7th day after sowing.

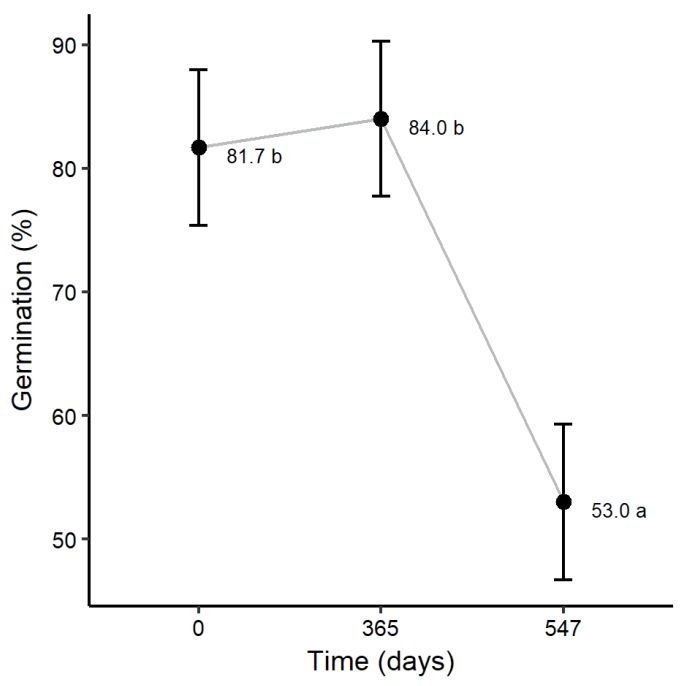

FIGURE I Average germination rate and confidence intervals (bars) for three storage periods for seeds of Quillaja brasiliensis. Means with same letters are not significantly different using the HDS Tukey test $(P<0.05)$.
Light and temperature

Temperature and photoperiod did not influence germination rate, which had a mean value of $83.19 \%$ for all treatments. However, temperature affected germination velocity index and mean germination time, while photoperiod influenced mean germination time and synchrony (Table I). Temperature and photoperiod did not show significant interaction for any variable. Seed moisture content was $8.53 \%$ (CV 2.83\%). The first germination occurred at the 3rd day and the last at the 14th day after sowing.

\section{Sowing methods}

Quillaja brasiliensis was tolerant to the sowing methods for germination rate and germination velocity index, and germination rates were similar to the light and temperature experiment. There were statistical differences for mean germination time for seeds sowed in cone-shaped plastic containers, with values two times greater compared to acrylic boxes. Similarly, the highest synchrony was for seeds sowed in acrylic germination

TABLE I Means for germination parameters of Quillaja brasiliensis in treatments that combined different levels of temperature and light (mean \pm standard error).

\begin{tabular}{|c|c|c|c|c|}
\hline Variable & Parameter & Level & Mean \pm SE & ANOVA \\
\hline \multirow{5}{*}{$\begin{array}{l}G \\
(\%)\end{array}$} & \multirow{2}{*}{$\begin{array}{c}\text { Temperature } \\
\left({ }^{\circ} \mathrm{C}\right)\end{array}$} & 20 & $84.17 \pm 2.19 a$ & \multirow{2}{*}{$0.38 \mathrm{~ns}$} \\
\hline & & 25 & $82.22 \pm 2.19 a$ & \\
\hline & \multirow{3}{*}{$\begin{array}{l}\text { Photoperiod } \\
\text { (hours) }\end{array}$} & 0 & $87.08 \pm 2.69 a$ & \multirow{3}{*}{$1.53 \mathrm{~ns}$} \\
\hline & & 12 & $80.83 \pm 2.69 a$ & \\
\hline & & 24 & $81.67 \pm 2.69 a$ & \\
\hline \multirow{5}{*}{$\begin{array}{c}\text { GVI } \\
\text { (days) }\end{array}$} & \multirow{2}{*}{$\begin{array}{c}\text { Temperature } \\
\left({ }^{\circ} \mathrm{C}\right)\end{array}$} & 20 & $5.80 \pm 0.23 a$ & \multirow{2}{*}{$9.53^{* * *}$} \\
\hline & & 25 & $6.77 \pm 0.23 b$ & \\
\hline & \multirow{3}{*}{$\begin{array}{l}\text { Photoperiod } \\
\text { (hours) }\end{array}$} & 0 & $6.25 \pm 0.29 a$ & \multirow{3}{*}{$0.38 \mathrm{~ns}$} \\
\hline & & 12 & $6.13 \pm 0.29 a$ & \\
\hline & & 24 & $6.46 \pm 0.29 a$ & \\
\hline \multirow{5}{*}{$\begin{array}{l}\text { MGT } \\
\text { (days) }\end{array}$} & \multirow{2}{*}{$\begin{array}{c}\text { Temperature } \\
\left({ }^{\circ} \mathrm{C}\right)\end{array}$} & 20 & $4.61 \pm 0.11 a$ & \multirow{2}{*}{29.72 *** } \\
\hline & & 25 & $3.82 \pm 0.11 b$ & \\
\hline & \multirow{3}{*}{$\begin{array}{l}\text { Photoperiod } \\
\text { (hours) }\end{array}$} & 0 & $4.46 \pm 0.13 a$ & \multirow{3}{*}{5.37 * } \\
\hline & & 12 & $4.29 \pm 0.13 \mathrm{ba}$ & \\
\hline & & 24 & $3.90 \pm 0.13 b$ & \\
\hline \multirow{5}{*}{ Z } & \multirow{2}{*}{$\begin{array}{c}\text { Temperature } \\
\left({ }^{\circ} \mathrm{C}\right)\end{array}$} & 20 & $0.40 \pm 0.03 a$ & \multirow{2}{*}{$2.68 \mathrm{~ns}$} \\
\hline & & 25 & $0.46 \pm 0.03 a$ & \\
\hline & \multirow{3}{*}{$\begin{array}{c}\text { Photoperiod } \\
\text { (hours) }\end{array}$} & 0 & $0.36 \pm 0.03 a$ & \multirow{3}{*}{$13.59^{* * *}$} \\
\hline & & 12 & $0.38 \pm 0.03 a$ & \\
\hline & & 24 & $0.55 \pm 0.03 b$ & \\
\hline
\end{tabular}

Means with same letters within a column are not significantly different using the HDS Tukey test $(P<0.05)$. Significance of ANOVA: *** $P<0.001$, ** $P<0.0$ I, * $P<0.05$, ns $P>0.05$. G germination, GVI germination velocity index, MGT mean germination time, $Z$ synchrony. 
boxes (TI; Table 2). The values of mean germination time and synchrony reflect the time required for the first and last germination during the experiment, that mean, while for $\mathrm{TI}$ it took only three days for first germination and seven for the last, for T2 the first germination occurred at the 7 th day and the last at the 24th. Seeds had a moisture of $8.00 \%$ (CV $4.26 \%$ ).

TABLE 2 Means for germination parameters of Quillaja brasiliensis seeds sowed in acrylic germination boxes (TI) and cone-shaped plastic containers (T2) (mean \pm standard error).

\begin{tabular}{cccc}
\hline Parameter & Treatment & Mean \pm SE & ANOVA \\
\hline G & TI & $84.00 \pm 3.42 \mathrm{a}$ & 3.82 \\
$(\%)$ & T2 & $74.54 \pm 3.42 \mathrm{a}$ & \\
\hline GVI & TI & $4.14 \pm 0.21 \mathrm{a}$ & \multirow{2}{*}{$0.01 \mathrm{~ns}$} \\
(day) & T2 & $4.12 \pm 0.2 \mathrm{a}$ & \\
\hline MGT & TI & $5.13 \pm 0.27 \mathrm{~b}$ & \multirow{2}{*}{$180.80 * * *$} \\
(day) & T2 & $10.19 \pm 0.27 \mathrm{a}$ & \\
\hline Z & TI & $0.57 \pm 0.02 \mathrm{~b}$ & $73.66 * * *$ \\
& T2 & $0.29 \pm 0.02 \mathrm{a}$ & \\
\hline
\end{tabular}

Means with same letters within a column are not significantly different using the Tukey HDS test $(P<0.05)$. Significance of ANOVA: *** $P<0.001$, ** $P<0.01$, * $P<0.05$, ns $P>0.05$. G germination, GVI germination velocity index, MGT mean germination time, $Z$ synchrony.

\section{Effect of transplanting on seedlings growth}

Seedlings demonstrated a high resistance to transplantation stress, with no significant difference regarding to direct sowed treatment, with survival rate up to $97 \%$. Slightly lower survival values were observed for the transplanted seedlings (Figure 2A). There were not significant differences among treatments with respect to height, steam diameter, HDR and number of leaves. During the experiment the height, number of leaves, HDR and diameters had a positive exponential increase. One-month old seedlings had an average height of 4.95-5.39 cm, diameter of $1.05-1.06 \mathrm{~mm}, \mathrm{HDR}$ of 4.67-5.10 and 4 leaves for transplanted and direct sowed treatments respectively. After four months, those parameters increased to $18.77-19.46 \mathrm{~cm}, 2.37-2.39 \mathrm{~mm}$, 7.77-8.55 and 33 leaves for transplanted and directsowed seedlings respectively (Figure 2B, 2C, 2D, 2E).

\section{DISCUSSION}

We have shown that $Q$. brasiliensis has a fast and high germination rate (up to $80 \%$ ) but that seed viability decreased after 1.5 year in storage. Temperature influenced on the velocity of germination and mean germination time showing that the higher temperature $\left(25^{\circ} \mathrm{C}\right)$ is better for germination viability and vigour parameters. Photoperiod influenced improving the
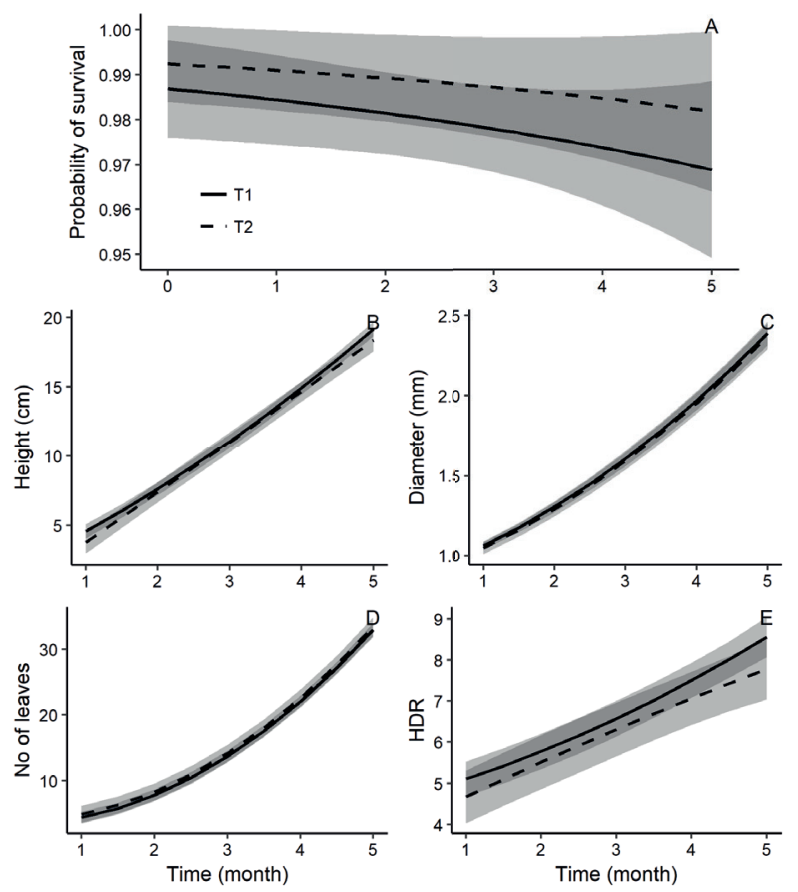

FIGURE 2 Means estimated along the time (lines) and confidence band (lighter areas) for Quillaja brasiliensis seedlings coming from directly sowing (TI) and transplanted (T2) for probability survival (A), total height (B), diameter at soil level $(C)$, height-diameter rate (D) and number of mature leaves $(E)$.

synchrony as shorter was the light period. The controlled environment of a germination chamber resulted in better and faster germination compared to the uncontrolled conditions of direct sowing. Transplantation did not have any negative effects on seedling survival and growth compared to seedlings from direct sowing.

Collection of seeds when mature is the crucial point when equilibrium with the microclimate is reached, and this is the optimal time to maximize de success of storage from seed (Hay and Probert, 20I3). The seed moisture content of $Q$. brasiliensis was similar that obtained by other researches for seeds from mature fruit (7.8-13\%) (Cantos, 2013; Mattei, 1995). The loss of viability of $Q$. brasiliensis in storage could be related to the degree of maturation of its fruits. Seeds collected at the final stage of dispersion, as in our research, are the best for storage (Cantos, 2009; Carvalho, 2003). The germination rate of $Q$. brasiliensis was similar to other studies with analogous storage conditions: $93 \%$ at 180 days for $Q$. brasiliensis (Cantos, 2009) and $83.3 \%$ after 365 days for $Q$. saponaria in cold storage with humidity control (Kuhlmann, 1991). However, our results were higher when compared to Mattei (1995) results for $Q$. brasiliensis, that reached only $20 \%$ after 300 days of 
storing. The best environment for storing seeds of this species is at low temperatures (Cantos, 2009; Mattei, 1995). We found that storing in a refrigerator in a plastic container is an efficient, simple and cheap way to obtain a viability rate of up to $50 \%$ after 1.5 years.

Seeds of many species have high germination rates independent of light condition (Baskin and Baskin, 20I4). The non-photoblastic behaviour of $Q$. brasiliensis could be related to its seed weight. In Panama seeds of pioneer species with mass $>2 \mathrm{mg}$ germinated equally well in light and darkness (Pearson et al., 2002); the germination of species with major seed mass was not influenced by light for a group of pioneer species from Brazilian seasonal forest (Válio and Scarpa, 200I). In our research germination of $Q$. brasiliensis was not influenced by temperature. However, for Cantos (2009) Q. brasiliensis presented better germination rates at $20^{\circ} \mathrm{C}$.

The highest mean germination time and synchrony index observed for seeds geminated in chamber is a result of the controlled conditions of temperature and humidity. However, the growth rate was not affected, with better performance when compared with values obtained by Cantos (2013). This author in an experiment using different substrates for $Q$. brasiliensis growth reached, at the end of 120 days, for the best treatment, the total height of $2.47 \mathrm{~cm}$ and an average number of 3.82 leaves, that represents six time less than in our experiment (c. 30 leaves). This difference could be a consequence that this species is light demanding, and the condition of natural light supplied in the nursery stimulated growth, whereas in the experiments of Cantos (2013) the seedlings were maintained in a laboratory.

Although knowledge of the ecology of germination and seedling growth is important for understanding plant recruitment and succession (Khurana and Singh, 200I), it can be difficult to determine the successional stage of a species based on the its seed characteristics, as proposed by Swaine and Whitmore (1988), because some species present mixed characteristics of distinct successional stage. $Q$. brasiliensis has been classified as both a pioneer (Carvalho, 2003) and a climax species (Cantos, 2009). For many species of the Atlantic Rain Forest there is no relationship between seed dormancy or non-dormancy and the successional group of species, and also in some taxa of the Chilean temperate rainforest, where most species showed moderate to high germination levels in the understorey, although their seedlings require high light levels for growth (Figueroa and Lusk, 200I).

A species could have a high germination rate, in nature its seeds could lie in sites with unsuitable condition for seedling recruitment. Post-emergence survival is highly variable and therefore germination cues are poor predictors of post-emergence recruitment success (Dalling et al., 20II). Considering the diversity of conditions in which $Q$. brasiliensis can germinate quickly and at a high rate allows us to infer that the factors limiting the establishment of the species occur after germination. These factors could be related to light, predation and loss of viability.

Although the high germination independence of light condition, $Q$. brasiliensis is a light demanding species, so seedlings that germinated in the field but growth in poor light condition could not survive longer. The species occurs in sunny areas on riverbanks and hills slopes in Uruguay (Santander and González, 2007) and southern Brazil (Soares and Ferrer, 2009). For Reitz (1996) this species begins the colonization of grassland forming forest patches in Santa Catarina plateau and remain in understorey of less dense forest. Damage as a result of the effects of pathogens, herbivores and falling debris is likely to affect seeds and seedling survival (Turner, 200I) and could have important effects on plant population dynamics (Kolb et al., 2007). Q. brasiliensis has been found to have injuries from pests during the reproductive phenophase, with flower predation caused by a species of Coleoptera (Cantos, 2009), and during the fructification with high infestation of their fruit in mature trees (Mattei, 1995). Infestation also occurs when its seed are sorted in room without temperature and moisture controlled (Carvalho, 2003). Concerning loss of viability, when storage at natural conditions this species lost viability faster (Carvalho, 2003). Such behaviour would represent a natural limitation for recruitment in nature. It was reported for the Chilean temperate rain forest that the scarcity of seedlings of some species under the canopy reflects poor seedling survival, rather than germination failure (Figueroa and Lusk, 200I).

These natural restrictions combined with habitat degradation and reduction and overexploitation could act together, causing $Q$. brasiliensis to be threatened. However, the species has some characteristics favourable for restoration, a high germination rate, rapid growth and no restriction for soil conditions (Carvalho, 2003), characteristics that qualify it as a potential species for restoring degraded areas and for enrichment programmes. As a result of our findings, I 40 seedlings originating from these experiments have been used in experimental enrichment plantings in three Araucaria Forests remnants. 


\section{CONCLUSION}

Quillaja brasiliensis has a fast and high germination rate (up to $80 \%$ ) but that seed viability decreased after 1.5 year in storage. Temperature influenced on the velocity of germination and mean germination time showing that the higher temperature $\left(25^{\circ} \mathrm{C}\right)$ is better for germination viability and vigour parameters. Photoperiod influenced improving the synchrony as shorter was the light period. The controlled environment of a germination chamber resulted in better and faster germination compared to the uncontrolled conditions of direct sowing. Transplantation did not have any negative effects on seedling survival and growth compared to seedlings from direct sowing.

\section{ACKNOWLEDGMENTS}

We thank Jeniffer Grabias, for the technical support. Martin Fisher and Marília Borgo for reviewing the manuscript. Also, acknowledge the financial support from the Fauna and Flora International, the Global Trees Campaign and the Conservation Leadership Program.

\section{REFERENCES}

BASKIN, C. C.; BASKIN, J. M. Seeds: ecology, biogeography, and evolution of dormancy and germination, 2 ed. Elsevier/AP, San Diego, CA. 2014. I586p.

CANTOS, A. A. Maturação Fisiológica, Comportamento das sementes durante $o$ armazenamento e classificação do grupo ecológico de sementes de Quillaja brasiliensis (A. St. Hil. \& Tul.) Mart. (Quillajaceae) e para a Região de Bagé RS. 2009. 42p. Master dissertation, Universidade Federal de Pelotas, Pelotas.

CANTOS, A. A. Metodologia para condução do teste de germinação e produção de mudas em diferentes substratos de Quillaja brasiliensis. 2013. 52p. Phd Thesis, Universidade Federal de Pelotas, Pelotas.

CARVALHO, P. E. R. Espécies arbóreas brasileiras. Embrapa Informação Tecnológica, Brasília. 2003. 1039p.

CNCFlora. Lista Vermelha da flora brasileira, Centro Nacional de Conservação da Flora. 2013. I 100p.

COSTA, F. DE; YENDO, A. C. A.; CIBULSKI, S. P.; FLECK, J. D.; ROEHE, P. M.; SPILKI, F. R.; GOSMANN, G. FETT-NETO, A. G. Alternative inactivated poliovirus vaccines adjuvanted with Quillaja brasiliensis or Quil-A Saponins are equally effective in inducing specific immune responses. PLoS ONE n.9, el05374, 2014.

DALLING, J. W.; DAVIS, A. S.; SCHUTTE, B. J.; ARNOLD, A. E. Seed survival in soil: interacting effects of predation, dormancy and the soil microbial community: Seed survival in soil. Journal of Ecology, v.99, n. I, p.89-95, 201 I.

FIGUEROA, J. A.; LUSK, C. H. Germination requirements and seedling shade tolerance are not correlated in a Chilean temperate rain forest. New Phytologist, v. I52, n. 3, p.483-489, 200 I.
HAY, F. R.; PROBERT, R. J. Advances in seed conservation of wild plant species: a review of recent research. Conservation Physiology, v. I, p. I-I I, 2013.

HOFFMANN, P. M.; BLUM, C. T.; VELAZCO, S. J. E.; GILL, D. J. C.; BORGO, M. Identifying target species and seed sources for the restoration of threatened trees in southern Brazil. Oryx, v.49, n.3, p.425-430, 2015.

IAPAR - Instituto Agronômico Do Paraná. Available at: http:// www.iapar.br/. Accessed in 09 Mach 2017.

KOLB, A.; EHRLEN, J. ERIKSSON, O. Ecological and evolutionary consequences of spatial and temporal variation in predispersal seed predation. Perspective in Plant Ecology and Evolution System, v.9, n.2, p.79-100, 2007.

KRITICOS, D. J.; WEBBER, B. L.; LERICHE, A.; OTA, N.; MACADAM, I.; BATHOLS, J.; SCOTT, J.K. 20I2. CliMond: global high resolution historical and future scenario climate surfaces for bioclimatic modelling. Methods in Ecology \& Evolution, v.3, p.53-64.

KUHLMANN, S. C. W. Factores que influyen en la germinación y producción de plantas de Quillay (Quillaja saponaria Mol.). 1991. 128p. Phd Thesis, Universidad de Chile, Santiago, Chile.

MARCHIORI, J. N. C. Dendrologia das angiospermas: das bixáceas às rosáceas. Universidade Federal de Santa Maria, Santa Maria, Santa Catarina, Brasil. 2000. 240p.

MARTINS, E.; LOYOLA, R.; MESSINA, T.; AVANCINI, R. MARTINELLI, G. Tree red listing in Brazil: Lessons and perspectives. Brazilian Geographical Journal, v. I 2, n.2, p.8-II. 2015.

MATTEI, V. L. Efeito do período de colheita na longevidade de sementes de timbauva (Quillaja brasilienis Martius). Revista Brasileira de Agrociência, v. I, n. 3, p. I33-136, 1995.

MORAES, M. A.; BORGES, R. A. X.; MARTINS, E. M.; FERNANDES, R. A.; MESSINA, T.; MARTINELLI, G. Categorizing threatened species: an analysis of the Red List of the flora of Brazil. Oryx, v.48, n.2, p.258-265, 2014.

MÜLLER, L. E., SCHIEDECK, G. Physical properties of botanical surfactants. Science of The Total Environment. v.6106II, p.II33-1137. 2018.

PEARSON, T. R. H.; BURSLEM, D. F. R. P.; MULLINS, C. E.; DALLING, J. W. Germination ecology of neotropical pioneers: interacting effects of environmental conditions and seed size. Ecology, v.83, n. I0, p.2798-2807, 2002.

R CORE TEAM. R: A language and environment for statistical computing. R Foundation for Statistical. 2017.

REITZ, R. Flora llustrada Catarinense: Rosáceas. Herbário Barbosa Rodrigues, Itajaí, Santa Catarina, Brazil. 1996. I35p.

SAKURAGUI, C. M. 20I5. Quillajaceae in Lista de Espécies da Flora do Brasil. Jardim Botânico do Rio de Janeiro. Available at: http://floradobrasil.jbrj.gov.br/jabot/ floradobrasil/FB I08400. Accessed in: 09 Mach 2017 
SANTANDER, C. A. B.; GONZÁLEZ, I. G. Flora arbórea del Uruguay: con énfasis en las especies de Rivera y Tacuarembó, I ed. COFUSA. 2007. 543p.

TABARELLI, M.; PINTO, L. P.; SILVA, J. M. C.; DA COSTA, C. M. R. Endangered species and conservation planning. In: GALINDO-LEAL, C.; CÂMARA, I. G. (Org.). The Atlantic Forest of South America: Biodiversity Status, Threats, and Outlook, I ed, State of the Hotspots. Island Press. 2003. p.86-94.
THOMAS, E.; JALONEN, R.; LOO, J.; BOSHIER, D.; GALLO, L.; CAVERS, S.; BORDACS, S.; SMITH, P.; BOZZANO, $M$. Genetic considerations in ecosystem restoration using native tree species. Forest Ecology and Management, v.333, p.66-75, 2014.

TURNER, I. M. The ecology of trees in the tropical rain forest. Cambridge University Press, Cambridge; New York. 200 I. 298p.

VÁLIO, I. F. M.; SCARPA, F. M. Germination of seeds of tropical pioneer species under controlled and natural conditions. Brazilian Journal of Botany, v.24, n. I, p.79-84, 200 I. 